\title{
THE NATURE OF THE TISSUE FLUID IN THE OEDEMA OF TOXAEMIA OF PREGNANCY
}

BY

\author{
C. L. MUKHERJEE AND A. D. T. GOVAN \\ From the Research Department, Glasgow Royal Maternity and Women's Hospital
}

(RECEIVED FOR PUBLICATION MARCH 22, 1950)

Very little is known about the nature of the tissue fluid in the oedema of pregnancy toxaemia. Most investigators (Dieckmann, 1942 ; Taylor, Warner, and Welsh, 1939 ; Chesley and Chesley, 1943) believe that the abnormal water balance in this condition is caused by a combination of several factors, both mechanical and physico-chemical in nature. There is general acceptance of the fact that the oedema in toxaemias of pregnancy is brought about by a retention of sodium chloride in the tissues, and some observers (Taylor et al., 1939) suggest that this is connected with an oestrogen excess which accompanies pregnancy. No attempt has, however, been made to study the properties of the oedema fluid and to determine if in preeclamptic oedema the normal physico-chemical equilibrium between the plasma and tissue fluid is in any way disturbed.

\section{Materials and Method}

The present investigation is based upon the chemical analysis of the plasma and tissue fluid collected from 45 cases of pre-eclampsia with varying degrees of oedema.

The tissue fluid was obtained from the subcutaneous tissue of the oedematous limb (usually the inferior extremity) with a No. 11 hypodermic needle. Before the fluid for analysis was collected in a test-tube the needle was connected to a water manometer to determine the tissue fluid pressure. Throughout the whole procedure care was taken to avoid any pressure not only on the part itself but also on the veins draining the limb, which was kept at rest at the cardiac level. Blood for analysis was obtained from the cubital vein at the same time as the tissue fluid. A portion of the tissue fluid and blood was collected under liquid paraffin for the estimation of bicarbonate. To evaluate the results obtained in toxaemias of pregnancy, values for normal pregnancy must be known. The difficulty in obtaining the subcutaneous tissue fluid in non-oedematous subjects is obvious and to overcome it samples of peritoneal fluid were obtained from six cases of normal pregnancy during caesarean section. In each case the specimen was collected from the anterior pelvic compartment immediately after laparotomy, care being taken to avoid spilling blood into the peritoneal cavity. The quantity of fluid obtained in this manner was small but was found sufficient for analytical purposes.

Tissue tension in normal pregnancy was measured by the same method as that employed for cases of toxaemia.

Standard methods (King, 1946 ; Peters and Van Slyke, 1932) for microanalysis were employed for all chemical estimations. Each estimation was done in duplicate and the results for all mineral constituents were expressed in milli-equivalents per litre. 
For the purposes of this description our cases of pre-eclamptic oedema have been divided into four groups. Group 1 consists of six cases with slight oedema confined to the feet and ankles only; Group 2, of 11 cases with pitting oedema of the feet, ankles, and legs; Group 3, of 12 cases with marked oedema of the inferior extremities with or without slight puffiness of the face and hands; and Group 4 contains 16 cases with generalized oedema.

\section{Physical Characteristics of the Tissue Fluid}

Both normal and oedematous tissue fluids are crystal clear in appearance. On standing for several hours a delicate, woolly coagulum forms. Unlike a fibrinous clot it does not retract even on prolonged standing. Admixture with a small quantity of fresh plasma or serum causes a marked reduction in clotting time and the clot is heavier and more retractile. The cellular constituents are scanty in both normal and toxaemic cases. Not more than 8 lymphocytes per c.mm. were found in either.

\section{Tissue Tension}

The effect of tissue tension in oedema has been studied by several investigators. Loeb (1923) suggested that a diminution in tissue tension might be responsible for the occurrence of oedema. Dieckmann (1942), on the other hand, observed that in the oedema of pre-eclampsia the tissue tension was increased.

We measured the tissue tension in a limb at cardiac level in 25 cases of normal pregnancy and in 45 patients suffering from pre-eclampsia. The results are shown in Table I.

TABLE I

Tissue Tension in Normal Pregnancy and Pregnancy Toxaemia

\begin{tabular}{|c|c|c|c|c|c|c|}
\hline & & \multirow{2}{*}{$\begin{array}{l}\text { Normal } \\
\text { Pregnancy }\end{array}$} & \multicolumn{4}{|c|}{ Pre-eclampsia } \\
\hline & & & Group 1 & Group 2 & Group 3 & Group 4 \\
\hline Oedema . & .. & 0 & & & & \\
\hline No. of cases & .. & 6 & 6 & 11 & 12 & 16 \\
\hline $\begin{array}{l}\text { Tissue tensio } \\
\text { Minimum }\end{array}$ & $\begin{array}{rr}\left.\text { Im. } \mathrm{H}_{2} \mathrm{O}\right): \\
\cdots\end{array}$ & 13.6 & 15.5 & 18.8 & 23.8 & 24.9 \\
\hline Maximum & .. & 21.0 & 26.3 & 30.0 & 34.0 & 34.7 \\
\hline Average. & .. & 18.25 & 19.7 & 22.7 & 26.6 & 30.1 \\
\hline Standard dev & . & 1.74 & 4.17 & 3.13 & 2.96 & 2.49 \\
\hline Significance & . & & - & + & + & + \\
\hline
\end{tabular}

It is evident that as oedema increases the tissue tension tends to rise. In generalized oedema the coefficient of variation of the values for tissue tension diminishes and is less than that in normal pregnancy. In the various degrees of oedema, however, there is considerable overlapping. From the time oedema becomes appreciable the maximum figures show little variation in the series, but the minimum values tend to rise. 
This increase in tissue tension, in the absence of other factors, will tend to reduce the effective filtration pressure and thereby limit the degree of oedema. In toxaemia, however, visible oedema does not affect loose areolar tissue (e.g., eyelids) until the condition is severe and extensive, although tissue tension is less in these regions. Progressive oedema with increasing tissue tension, in the absence of an active fluid-shift, presupposes a progressively rising intracapillary pressure. It has already been shown that the level of blood pressure bears no consistent relationship with oedema (Mukherjee and Govan, 1950).

When the limb is subjected to the effects of gravity the tension within the tissues increases considerably. In normal pregnancy the tissue pressure was raised by $52.5 \%$ after 20 minutes. In patients with pre-eclamptic oedema a similar treatment caused the tension to increase by $106.2 \%$ of the basic level. This is in agreement with an observation made by Burch and Sodeman in 1938, who found that venous compression of a limb in a normal subject may raise the tissue pressure by $20 \mathrm{~mm}$. The average increase in tissue tension caused by the effects of gravity for 20 minutes was $9.3 \pm 2.1 \mathrm{~mm}$. in normal pregnancy and $29.1 \pm 3.3$ in pre-eclamptic oedema. It is of interest to know that in all toxaemic patients gravity caused the tissue pressure to rise above the normal intracapillary pressure. However, no correlation was found between the tissue tension and the brachial arterial pressure in any instance.

\section{Organic Constituents of Tissue Fluids}

Protein.-Tissue fluid was consistently found to be poor in protein in all cases. In six normal cases it was found to contain only $0.2 \mathrm{~g} . \%$ of protein with a range of values between 0.27 and $0.16 \mathrm{~g}$. per $100 \mathrm{ml}$. The protein content of the fluid bore no relationship to that of the plasma.

In 26 cases of toxaemia of varying severity the average protein concentration of the tissue fluid was $0.24 \mathrm{~g}$. per $100 \mathrm{ml}$. The maximum and minimum values were 0.32 and $0.17 \mathrm{~g}$. per $100 \mathrm{ml}$. respectively. The difference between the averages of normal and toxaemic cases had no statistical significance.

Estimation of the individual protein fractions was undertaken in two normal and 12 toxaemic cases. The globulin content was low in all instances, although it showed a slight variation relative to the total protein content of the fluid. As a result the albumin: globulin ratio was fairly constant. The results are given in Table II.

The albumin : globulin ratio was alike in both normal and toxaemic pregnancy and considerably higher than that of the plasma. No relationship could be found between the ratio for tissue fluid and that of the corresponding plasma, nor did the variation in the ratio correspond with the degree of oedema.

Only a trace of fibrinogen could be found in the tissue fluid of both normal and toxaemic cases. Indirect estimations using thromboplastin (Russell viper venom) were made in seven patients, the difference in nitrogen content of the fluid before and after clotting being regarded as due to fibrinogen. The results varied from 1 to $3 \%$ of the total protein. Gravity was not found to alter the protein content of the tissue fluid.

The protein content of the tissue fluid in pre-eclamptic oedema has been studied by other observers (Hellmuth, 1922; Albano, 1927) and our findings corroborate their results. 
TABLE II

Proteins of Plasma and Tissue fluid in Normal and Toxaemic Pregnancy

\begin{tabular}{|c|c|c|c|c|c|c|c|c|}
\hline \multirow{2}{*}{\multicolumn{2}{|c|}{ Patient }} & \multirow{2}{*}{$\begin{array}{l}\text { Maturity } \\
\text { (weeks) }\end{array}$} & \multirow{2}{*}{$\begin{array}{c}\text { Blood } \\
\text { Pressure } \\
(\mathrm{mm} . \mathrm{Hg})\end{array}$} & \multirow{2}{*}{$\underset{\text { (g./litre) }}{\text { Albumin }}$} & \multirow{2}{*}{ Oedema } & \multicolumn{2}{|c|}{ Tissue Fluid } & \multirow{2}{*}{$\frac{\text { Plasma }}{\begin{array}{c}\text { A/G } \\
\text { Ratio }\end{array}}$} \\
\hline & & & & & & $\begin{array}{l}\text { Protein } \\
(\text { g. } \%)\end{array}$ & $\begin{array}{l}\text { A/G } \\
\text { Ratio }\end{array}$ & \\
\hline $\begin{array}{l}\text { हే } \\
\text { है } \\
\text { Z }\end{array}$ & $\begin{array}{lll}1 & 0 . & \ldots \\
2 & \mathrm{~S} . & \cdots \\
\end{array}$ & $\begin{array}{l}37 \\
39\end{array}$ & $\begin{array}{l}120 / 70 \\
116 / 72\end{array}$ & $\begin{array}{r}\mathbf{0} \\
\mathbf{0}\end{array}$ & $\begin{array}{l}- \\
-\end{array}$ & $\begin{array}{l}0.21 \\
0.17\end{array}$ & $\begin{array}{l}2.14 \\
2.11\end{array}$ & $\begin{array}{l}1.51 \\
1.49\end{array}$ \\
\hline 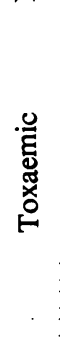 & $\begin{array}{rrr}1 & \text { McG. } \\
2 & \text { St. } & . . \\
3 & \text { C. } & . . \\
4 & \text { T. } & . . \\
5 & \mathrm{~K} . & . . \\
6 & \mathrm{~N} . & . . \\
7 & \text { McA. } \\
8 & \text { McN. } \\
9 & \text { O'R. } \\
10 & \text { H. } & . \\
11 & \text { B. } & . . \\
12 & \text { G. } & . .\end{array}$ & $\begin{array}{l}36 \\
36 \\
34 \\
39 \\
32 \\
34 \\
37 \\
40 \\
33 \\
36 \\
36 \\
40\end{array}$ & $\begin{array}{l}150 / 100 \\
170 / 104 \\
160 / 100 \\
160 / 105 \\
180 / 110 \\
175 / 100 \\
165 / 100 \\
185 / 120 \\
165 / 105 \\
178 / 120 \\
150 / 102 \\
168 / 105\end{array}$ & $\begin{array}{r}3 \\
8 \\
2 \\
4 \\
10 \\
8 \\
3 \\
6 \\
5 \\
6 \\
4 \\
5\end{array}$ & $\begin{array}{c}++ \\
+++ \\
++ \\
+++ \\
+++ \\
++ \\
++ \\
+++ \\
++ \\
+++ \\
++ \\
+++\end{array}$ & $\begin{array}{l}0.19 \\
0.23 \\
0.20 \\
0.34 \\
0.18 \\
0.29 \\
0.23 \\
0.19 \\
0.24 \\
0.17 \\
0.21 \\
0.28\end{array}$ & $\begin{array}{l}2.06 \\
2.13 \\
2.11 \\
2.12 \\
2.10 \\
2.09 \\
2.12 \\
2.14 \\
2.09 \\
2.10 \\
2.13 \\
2.13\end{array}$ & $\begin{array}{l}1.10 \\
1.23 \\
1.27 \\
1.05 \\
1.17 \\
1.24 \\
1.22 \\
1.06 \\
1.14 \\
1.13 \\
1.26 \\
1.11\end{array}$ \\
\hline \multicolumn{6}{|c|}{$\begin{array}{r}\text { Average (toxaemic) } \\
\text { Standard deviation (toxaemic) }\end{array}$} & $\begin{array}{l}0.23 \\
0.07\end{array}$ & $\begin{array}{l}2.12 \\
0.02\end{array}$ & $\begin{array}{l}1.16 \\
0.085\end{array}$ \\
\hline
\end{tabular}

Urea, Non-protein Nitrogen, Creatinine, Uric Acid, and Sugar.-These substances were found in identical concentration in plasma and tissue fluid. Our results obtained in normal and toxaemic pregnancy are presented in Table III.

In view of the freely diffusible nature of these substances it is reasonable to expect that they would be equally distributed between plasma and tissue fluid. Dieckmann (1942), however, has stated that the tissue fluid is probably richer in urea than blood. Findings in this laboratory do not substantiate this, but they agree with those of other authors' investigations on experimental oedema and ascites (Greene, Bollman, Keith, and Wakefield, 1931 ; Hastings, Salvesen, Sendroy, and Van Slyke, 1927).

TABLE III

Organic Constituents of Plasma and Tissue Fluid

\begin{tabular}{|c|c|c|c|c|c|c|}
\hline & & & \multicolumn{2}{|c|}{$\begin{array}{c}\text { Normal Pregnancy } \\
\text { (6 Cases) }\end{array}$} & \multicolumn{2}{|c|}{$\begin{array}{l}\text { Pre-eclampsia } \\
\text { (26 Cases) }\end{array}$} \\
\hline & & & Plasma & Tissue Fluid & Plasma & Tissue Fluid \\
\hline$\overline{\text { Urea }}$ & $\ldots$ & . & $26.0 \pm 1.43 * \dagger$ & $26.0 \pm 1.43$ & $22.4 \pm 3.28$ & $22.3 \pm 3.60$ \\
\hline N.P.N. & $\ldots$ & .. & $\begin{array}{l}28.3 \pm 1.39 \\
23.1-33.2\end{array}$ & $\begin{array}{l}28.2 \pm 1.40 \\
22.6-33.0\end{array}$ & $\begin{array}{l}32.5 \pm 1.54 \\
22.6-40.0\end{array}$ & $\begin{array}{l}32.5 \pm 1.54 \\
23.3-39.3\end{array}$ \\
\hline Creatinine & . & .. & $1.24 \pm 0.094$ & $\begin{array}{l}1.25 \pm 0.087 \\
1.10-1.58\end{array}$ & $\begin{array}{l}1.25 \pm 0.094 \\
1.16-1.60\end{array}$ & $\begin{array}{l}1.26 \pm 0.087 \\
1.20-1.56\end{array}$ \\
\hline Uric acid & . & .. & $3.79 \pm 0.41$ & $3.80 \pm 0.41$ & $5.0 \pm 0.39$ & $5.0 \pm 0.39$ \\
\hline Sugar .. & .. & .. & $\begin{array}{l}3.0-4.45 \\
91.4 \pm 4.25 \\
86.2-98.3\end{array}$ & $\begin{array}{l}3.0-4.43 \\
91.5 \pm 4.72 \\
86.0-97.8\end{array}$ & $\begin{array}{r}4.38-6.10 \\
82.4 \pm 4.01\end{array}$ & $\begin{array}{l}4.40-6.0 \\
82.4 \pm 2.80 \\
79.4-94.0\end{array}$ \\
\hline
\end{tabular}

* All results are expressed in $\mathrm{mg} . / 100 \mathrm{ml}$

+ The above figures in each case represent the average together with the probable error and the minimum and maximal values. 
Cholesterol and Phospholipoids.-The concentration of the cholesterol in the plasma was higher than that of tissue fluid in both normal and toxaemic cases, and no correlation could be found between the two levels. The average plasma cholesterol level in normal pregnancy was $238.6 \mathrm{mg}$. per $100 \mathrm{ml}$. and that of the tissue fluid $66.4 \mathrm{mg}$. per $100 \mathrm{ml}$. In pre-eclampsia the plasma cholesterol level increased to $271.6 \mathrm{mg}$. per $100 \mathrm{ml}$., but the tissue fluid cholesterol level was only $65.9 \mathrm{mg}$. per $100 \mathrm{ml}$. The increase in the plasma cholesterol level thus appears to have no effect on the value for tissue fluid. The highest tissue fluid cholesterol level observed was $83.5 \mathrm{mg}$. per $100 \mathrm{ml}$, and this was in a patient who was only moderately toxic, with a plasma cholesterol level of $242 \mathrm{mg}$. per $100 \mathrm{ml}$.

The behaviour of lipoid phosphorus was in striking contrast to that of cholesterol. In normal pregnancy the lipoid phosphorus was almost equally distributed between plasma and tissue fluid, the average values being $12.7 \mathrm{mg}$. per $100 \mathrm{ml}$. and $12.6 \mathrm{mg}$. per $100 \mathrm{ml}$. respectively. In toxaemia, however, the average value for the tissue fluid lipoid phosphorus was $20.8 \mathrm{mg}$. per $100 \mathrm{ml}$. while that of the plasma was $14.5 \mathrm{mg}$. per $100 \mathrm{ml}$. The difference between these two values was statistically significant. The change was not confined to the average but was reflected also in the maximum and minimum values. It has been suggested (Boyd, 1935) that the retention of phospholipoids, because of their hydrophilic properties, might be responsible for the accumulation of oedema fluid. The results have therefore been analysed in relation to the degree of clinical oedema, and are shown in Table IV. It is obvious from our findings that although the tissue fluid lipoid phosphorus is raised in oedematous patients the value does not bear any consistent relationship with the severity of the oedema.

TABLE IV

Phospholipoids of Tissue Fluid

\begin{tabular}{|c|c|c|c|c|c|}
\hline & & \multirow{2}{*}{$\begin{array}{l}\text { Normal } \\
\text { Pregnancy }\end{array}$} & \multicolumn{3}{|c|}{ Pre-eclamptic Oedema } \\
\hline & & & Group 2 & Group 3 & Group 4 \\
\hline $\begin{array}{ll}\text { No. of cases } & . . \\
\text { Minimum } & . \\
\text { Maximum } & . \\
\text { Average } & . \\
\text { Standard deviation } \\
\text { Significance } \quad .\end{array}$ & $\begin{array}{l}. . \\
\cdots \\
\cdots \\
\cdots \\
\cdots \\
.\end{array}$ & $\begin{array}{c}6 \\
9.5^{*} \\
15.9 \\
12.7 \\
1.66\end{array}$ & $\begin{array}{l}4 \\
16.6 \\
21.3 \\
19.6 \\
2.27 \\
+\end{array}$ & $\begin{array}{l}11 \\
17.0 \\
23.0 \\
20.1 \\
1.83 \\
-\end{array}$ & $\begin{array}{l}11 \\
19.7 \\
24.0 \\
22.0 \\
1.50 \\
+\end{array}$ \\
\hline
\end{tabular}

* All results expressed as $\mathrm{mg}$. lipoid $\mathrm{P}$ per $100 \mathrm{ml}$.

\section{Concentration of Electrocytes in the Plasma and Tissue Fluid}

Each mineral constituent of the plasma and tissue fluid was estimated separately. Owing to the practical difficulty of estimating the various organic acids (hydroxy, ketonic, and oxyproteinic) the concentration of total organic acids was calculated from the difference between the total kation and the anion plus protein concentration of the fluids. In a small number of cases the lactic acid content of the plasma and tissue fluid was estimated. The results in normal pregnancy and in the four groups of pre-eclamptic oedema are shown in Table V. Before discussing these figures it is necessary to consider the manner in which osmotic equilibrium between 


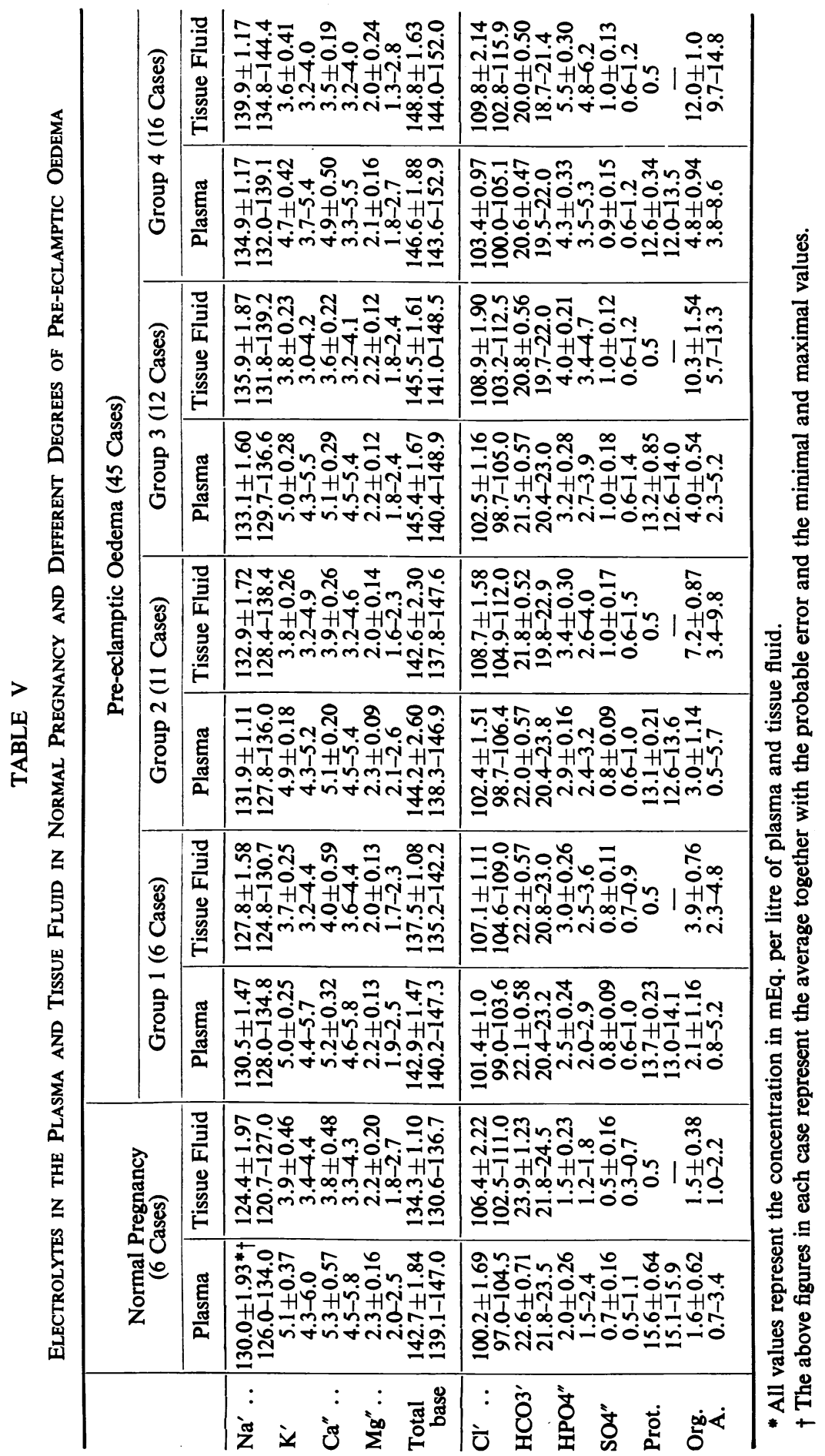


plasma and tissue fluid is achieved. When equilibrium is established the levels which the various ingredients attain are not related to their absolute concentrations by volume in the two media, but to the weight of the water in which they are dissolved. This is of little significance when dealing with freely diffusible solutes, but it is of some consequence when comparing plasma and tissue fluid. The large molecules of protein displace a considerable amount of the water in which they are dissolved. A litre of plasma containing 7\% protein holds only $935 \mathrm{~g}$. of water. The plasma water estimated in four normal cases was found to vary between 937 and 944 with an average of $940 \mathrm{~g}$. per $100 \mathrm{~g}$. of plasma. The water content of tissue fluid (average of six cases) was $980 \mathrm{~g}$. Plasma contains approximately 16 milli-equivalents of protein whereas the tissue fluid only holds about 0.5 Thus, if the concentrations of the solutes are expressed in terms of weight per volume of plasma and tissue fluid the results may suggest that these fluids do not obey Donnan's law of equilibrium. It can therefore be understood that the marked difference in protein concentration on either side of the capillary membrane makes a readjustment of the electrolyte levels in the two fluids necessary. At the $p H$ of plasma the proteins act as anions and therefore a diminished concentration of the total base can be expected. Thus the concentration of sodium, potassium, and calcium in the normal tissue fluid is found to be less than that of the plasma. The extremely low protein content of the tissue fluid, on the other hand, calls for a relatively higher concentration of anions to maintain equilibrium. The actual values of both kations and anions, however, do not quite agree with theoretical levels. Potassium and calcium form physiologically inert compounds with proteins, and the anions are affected by the constant flow of carbonic acid from the tissues to the plasma and the resulting chloride shift. These factors are not of themselves important, and, provided that the variation in the percentage of water in the two fluids is taken into consideration; it is found that plasma and tissue fluid obey Donnan's law.

Analysis of the data indicates the similarity between the electrolyte pattern of the plasma and that of tissue fluid in normal pregnancy. The total base concentration of the plasma is to some extent less than that in non-pregnant subjects, a finding which is in accord with that of other investigators (Dieckmann, 1942). This is probably caused by the decrease in the concentration of plasma proteins resulting in a relative increase of plasma water. On the basis of the figures given above for the water content of plasma and tissue fluid it would appear that the electrolyte partition between these two fluids closely approximates the theoretical values. $B_{P} / B_{T}{ }^{*}$ is 1.108 and $A_{T} / A_{P}$ is 1.010. The slight excess of base in the plasma is related to the higher concentration of protein. The difference in the base concentration between these two fluids is 14.8 milli-equivalents per $1,000 \mathrm{~g}$. of water, which almost corresponds to the milli-equivalent value of the plasma proteins. These findings for the plasma-tissue fluid ratios of base and acid agree with those observed by Greene et al. (1931) in experimental dialysates. The concentration of the anions in the tissue fluid is almost identical with that of the plasma. Phosphates, sulphates, and organic acids are slightly reduced in the tissue fluid. Chlorides are slightly in excess, and carbonates are practically equally distributed on either side of the

${ }^{*} B_{p}, B_{r}, A_{r}, A_{r}$ represent concentrations respectively of total base and total acid per litre of serum water or tissue fluid water. 
TABLE VI

Tissue Fluid Ratio of Electrolytes in Plasma in Normal Pregnancy and Pre-eclamptic Oedema

\begin{tabular}{|c|c|c|c|c|c|c|c|c|c|c|c|}
\hline & $\mathrm{Na}^{\prime}$ & $\mathbf{K}^{\prime}$ & $\sqrt{\mathrm{Ca}^{\prime \prime}}$ & $\sqrt{\mathrm{Mg}^{\prime \prime}}$ & $\Sigma \mathrm{B}$ & $\mathrm{Cl}^{\prime}$ & $\mathrm{HCO}_{3}{ }^{\prime}$ & $\sqrt{\mathrm{HPO}_{4}}$ & $" \sqrt{ } \overline{\mathrm{SO}_{4}}{ }^{\prime \prime}$ & Or.A & $\Sigma$ A. \\
\hline $\begin{array}{l}\text { Normal } \\
\text { nancy ( } 6 \text { cases) }\end{array}$ & 1.061 & 1.130 & 1.197 & 1.036 & 1.153 & 0.980 & 0.098 & 1.179 & 1.173 & 1.111 & 0.996 \\
\hline $\begin{array}{c}\text { Pre-eclampsia: } \\
\text { Group } 4 \text { (16 } \\
\text { cases) }\end{array}$ & 0.992 & 1.325 & 1.189 & 1.035 & 1.012 & 0.971 & 1.054 & 0.900 & 1.971 & 2.400 & 0.929 \\
\hline
\end{tabular}

capillary membrane. The excess of chloride is more apparent than real. The true difference is only 2 milli-equivalents per $1,000 \mathrm{~g}$. of water. The ratio of the anions in the plasma and tissue fluid is shown in Table VI. It is obvious from these figures that the nature of the tissue fluid in normal pregnancy does not vary from that of the non-pregnant subject.

The composition of the plasma and tissue fluid scarcely varied from normal in minor degrees of pre-eclamptic oedema. If, however, the figures for the various groups are examined certain changes become obvious. These are considered under their respective headings.

Increase of Plasma Electrolytes.-There is a slight rise in the concentration of the plasma electrolytes. This is not due to haemo-concentration, for, with the fall in proteins, the water content of the plasma actually increases. In four cases of generalized oedema we found the plasma water to vary between $949 \mathrm{~g}$. and $960 \mathrm{~g}$. with an average of $954 \mathrm{~g}$. per litre. However, the actual increase in electrolytes is only 2 milli-equivalents per $1,000 \mathrm{~g}$. of water. Examination of the individual constituents shows that there is a progressive increase of plasma sodium as the oedema becomes worse. In severe cases it is raised by 3.1 milli-equivalents per $1,000 \mathrm{~g}$. of plasma water, and it is accompanied by a decrease in the concentration of other kations to the extent of just over 1 milli-equivalent. In view of the highly active nature of sodium ions these changes are probably of a compensatory nature.

On the acid side the change principally affects the organic acids and inorganic phosphates. The concentration of the former in severe cases is raised by 3.2 milliequivalents or $200 \%$ and that of the latter by 2.3 milli-equivalents or $115 \%$ above the level in normal pregnant subjects. There is little change in the true concentration of the chlorides. The same holds good for sulphates, but the bicarbonates decrease by 3.3 milli-equivalents per $1,000 \mathrm{~g}$. of plasma water or $13.3 \%$ of the normal value. There is thus a slight positive balance of plasma anions in cases of oedema. This is shown by the kation : anion ratio. In normal pregnancy this is 1.123 and in cases of generalized oedema it is 1.094 .

Increase of Tissue Fluid Electrolytes.-The increase in electrolytes is more marked in the tissue fluid than in the plasma. The total increase amounts to 14.5 milli-equivalents per 1,000 g. of tissue water (compared with 2 milli-equivalents per $1,000 \mathrm{~g}$. of plasma water). This is 7.25 times the corresponding increase in the plasma. The disproportionate rise in tissue fluid electrolytes is contrary to the 
ordinary mechanism of tissue fluid formation and indicates that the retention of fluid in the tissue spaces is the result of some active process which upsets the normal equilibrium existing on either side of the capillary membrane. The qualitative changes, however, run parallel with those in the plasma, and the increase in electrolytes is brought about by changes in the sodium, phosphates, and organic acids. The concentration of sodium rises by 25.3 milli-equivalents or $20.2 \%$ of the normal level. As in the plasma this is accompanied by a slight fall in the other kations. The organic acids, phosphates, and chlorides all show an increase. The rise in chlorides, however, is only 3.4 milli-equivalents, which is almost the same as the increase in the plasma. The partition of chloride in plasma and tissue fluid in oedematous patients thus remains the same as in normal pregnancy. The organic acids are raised by more than 10 milli-equivalents or $700 \%$ and the phosphates by 4 milli-equivalents per $1,000 \mathrm{~g}$. water or $266 \%$ of the normal. There is a fall in bicarbonate by 3.9 milli-equivalents.

Partition of Electrolytes between Plasma and Tissue Fluids.-In normal pregnancy the partition of electrolytes between plasma and tissue fluid is in fair agreement with the formula $B_{P} / B_{T}=A_{T} / A_{P}$. In toxaemia, however, these ratios are disturbed, and with marked oedema. $\quad B_{P} / B_{T}$ is 1.012 , but $A_{T} / A_{P}$ is 1.076. This indicates that in these cases there is a retention of electrolytes in the tissues. As can be seen from Table VI the retention is mainly due to an increase in sodium, organic acids, and phosphates, and the sodium is apparently combined with these anions. Theoretically the ratio of plasma phosphates to tissue fluid phosphates should be lèss than unity, but it is slightly more, both in normal pregnancy and in experimental dialysates. This is usually explained on the assumption that the phosphates of the plasma exist partly in a non-diffusible form. In toxaemia the position is reversed and the non-diffusible tissue fluid phosphates are obviously increased. According to Greenberg, Larson, and Tufts (1935) and Grollman (1927) when the plasma phosphates rise above a certain level it forms non-diffusible salts with calcium. The reduced concentration of calcium in the tissue fluid makes such an explanation impossible in cases of toxaemia of pregnancy, and it seems more likely that the phosphates exist in complex combination with organic substances.

\section{Discussion}

The physical factors and variations in capillary permeability can play only a minor role in the causation of oedema in pre-eclamptic toxaemia. It is possible that these factors increase the severity of oedema, but they play little or no part in the initiation and maintenance of the process. It has been pointed out that in these cases there is a progressive fall in plasma proteins, and this of itself by its effect on osmotic pressure may tend to cause oedema. This change, however, cannot be responsible for the progressive accumulation of fluid in the tissue spaces. A continual outflow of fluid from the plasma would soon restore the normal level of colloid osmotic pressure and conditions would tend to return to normal. The critical level of colloid osmotic pressure of the plasma in relation to oedema is $20 \mathrm{~cm}$. of water. Dieckmann (1942) observed that the oncotic pressure in 15 cases of normal pregnancy was $28.7 \mathrm{~cm}$. of water, and in 14 cases of toxaemia the figure was $24.9 \mathrm{~cm}$. of water. We have studied the oncotic pressure in 45 cases of toxaemia and in only 
11 was the value below the critical level. In addition, these 11 cases included patients with varying degrees of oedema, some of them minor. Visible oedema was also noted in six cases in which the colloid osmotic pressure of the plasma was above $24 \mathrm{~cm}$. of water.

None of the other organic constituents, with the exception of organic acids and phosphates, appear to bear any relation to the onset and progress of toxaemic oedema of pregnancy. There would, however, appear to be justification for suggesting that the process is associated with the changes in the concentration of sodium, phosphorus, and organic acids. We have not found chloride to play any part other than a passive one in the mechanism. It seems reasonable to suggest that the sodium is retained in the tissues to neutralize the excess of anions. Whether the retention of sodium is an active process due to hyperactivity of the adrenal cortex cannot at present be decided. Our own studies tend to indicate that if such a mechanism is at work it is of a secondary nature.

We would suggest that the primary factor in the oedema of toxaemia of pregnancy is a disorder of metabolism, probably related to carbohydrate, resulting in an excess of organic acids and phosphates in the tissue fluids. Why these substances are retained is difficult to say, and an answer awaits further investigation.

\section{Summary}

A comparative study of the relative concentration of electrolytes in the plasma and tissue fluid in six cases of normal pregnancy and 45 cases of pre-eclamptic cedema showed that in normal pregnancy the electrolytic pattern on either side of the capillary membrane is the same as that in non-pregnant persons and in experimental conditions, although the total concentration of electrolytes in these regions in pregnancy is slightly less than that in the non-gravid state.

In pre-eclampsia there is an increased concentration of electrolytes in the tissue fluid. This change progresses as the oedema increases in severity. The raised level of electrolytes in the tissue fluid is due to an active retention of sodium in the tissue spaces, associated with a corresponding retention of organic acids and inorganic phosphates in this region. There is no evidence of retention of chlorides in the tissue fluid in pre-eclamptic oedema. It is suggested that the increased concentration of organic acids and phosphates is related to an upset in tissue carbohydrate metabolism.

\section{REFERENCES}

Albano, G. (1927). Folia Gynaec., 24, 81.

Boyd, E. M. (1935). Amer. J. Obstet Gynec., 30, 323.

Chesley, L. C., and Chesley, E. R. (1943). Amer. J. Obstet. Gynec., 45, 748.

Dieckmann, W. J. (1942). Toxemias of Pregnancy. London.

Greenberg, D. M., Larson, C. E., and Tufts, E. V. (1935). Proc. Soc. exp. Biol., N.Y., 32, 647.

Greene, C. H., Bollman, J. L., Keith, N. M., and Wakefield, E. G. (1931). J. biol. Chem., 91, 203. Grollman, A. (1927). Ibid., 72, 565 .

Hastings, A. B., Salvesen, H. A., Sendroy, J., and Van Slyke, D. D. (1927). J. gen. Physiol., 8, 701. Hellmuth, K. (1922). Zbl. Gynäk., 46, 290.

King, E. J. (1946). Micro-Analysis in Medical Biochemistry. London.

Loeb, L. (1923). Oedema. Baltimore.

Mukherjee, C., and Govan, A. D. T. (1950). In the press.

Peters, J. P., and Van Slyke, D. D. (1932). Quantitative Ciinical Chemistry, vol. 2. London.

Taylor, H. C., Warner, R. C., and Welsh, C. A. (1939). Amer. J. Obstet Gynec., 38, 748. 